DOI: $10.17957 / \mathrm{IJAB} / 15.1796$

http://www.fspublishers.org

\title{
Organic Fertilizer Regulates Soil Carbon, Nitrogen Balance and Greenhouse Gas Emissions in Tobacco Production System
}

\author{
Taibo Liang ${ }^{1}$, Huaxin Dai ${ }^{1}$, Qingli Liu ${ }^{2}$, Zhen Zhai ${ }^{1}$, Aiguo Wang ${ }^{1}$ and Yanling Zhang ${ }^{1 *}$ \\ ${ }^{1}$ Zhengzhou Tobacco Research Institute of China National Tobacco Corporation, Zhengzhou 450001, P. R. China \\ ${ }^{2}$ Institute of Agricultural Resources and Regional Planning of Chinese Academy of Agricultural Sciences, Beijing \\ 100081, P. R. China \\ *For correspondence: zhangyanling@ztri.com.cn
}

Received 05 December 2020; Accepted 20 March 2021; Published 10 May 2021

\begin{abstract}
The impact of organic fertilizers on the carbon source/sink balance of tobacco soil ecosystem remains controversial. A twoyear field experiment was conducted to investigate the effects of different fertilization treatments (no fertilizer, chemical fertilizer, chemical fertilizer and organic fertilizer) on greenhouse gas $(\mathrm{GHG})$ emissions including soil carbon dioxide $\left(\mathrm{CO}_{2}\right)$, nitrous oxide $\left(\mathrm{N}_{2} \mathrm{O}\right)$, ammonia volatilization and comprehensive greenhouse effects. The results showed that tobacco soil ecosystem can be carbon source or sink, depending mainly on the carbon sequestration of the plant. Comparing with chemical fertilizer, the combined application of chemical fertilizer and organic fertilizer increased the $\mathrm{CO}_{2}$ emission flux and $\mathrm{C}$ emission from soil, and significantly increased the carbon sequestration of tobacco plants. The carbon sequestration function of organic fertilizer was closely related to the carbon accumulation of tobacco plants. Compared with the chemical fertilizer, soil ammonia volatilization and $\mathrm{N}_{2} \mathrm{O}$ emission flux were increased by adding organic fertilizer. Both the soil $\mathrm{N}$ emission and the biological nitrogen fixation were increased by organic fertilizer. The greenhouse gas emission intensity (GHGI) of organic fertilizer treatment decreased by $14.60 \%$, a remarkable emission reduction, while the tobacco yield of organic fertilizer treatment increased $19.12 \%$. Therefore, increasing organic fertilizer in tobacco planting fields is an important way to promote tobacco yield, carbon sequestration and emission reduction. (C) 2021 Friends Science Publishers
\end{abstract}

Keywords: Organic fertilizer; Tobacco (; Carbon nitrogen balance; Greenhouse gas emission

\section{Introduction}

Climate change is the most serious global environmental problem facing humanity in the world today. The main reason for the global greenhouse effect is the greenhouse gases $(\mathrm{GHG})$, including carbon dioxide $\left(\mathrm{CO}_{2}\right)$, nitrous oxide $\left(\mathrm{N}_{2} \mathrm{O}\right)$ and methane $\left(\mathrm{CH}_{4}\right)$ (Tian et al. 2016) produced by agricultural production activities, such as land-use change, agriculture and waste management. According to United States Environmental Protection Agency (USEPA 2006), $\mathrm{CH}_{4}$ and $\mathrm{N}_{2} \mathrm{O}$ emissions from agricultural land use activities account for $50 \%$ and $75 \%$ of total global emissions, respectively. Therefore, agricultural GHG emission reduction plays an important role in controlling global climate change. Soil is a huge carbon pool in terrestrial ecosystems. Soil can be carbon source or carbon sink and affects the concentration of $\mathrm{CO}_{2}$ in the atmosphere (Duiker and Lal 1999). Many studies around the world have shown that soil carbon sequestration can be facilitated by appropriate land use and agricultural management (Poeplau and Don 2015; Lange et al. 2015; Gao et al. 2018). According to the Intergovernmental Panel on Climate
Change (IPCC), the technological potential of global agricultural emissions reduction is as high as $5500-6000 \mathrm{Mt}$ $\mathrm{CO}_{2}$ equivalent per year (Smith et al. 2007). Of these, $89 \%$ came from reducing soil $\mathrm{CO}_{2}$ emissions (e.g., soil carbon sequestration). Therefore, improving fertilizer use efficiency through reasonable farming measures and increasing carbon sequestration in crop soil systems are important ways to reduce $\mathrm{GHG}$ emissions in agriculture.

The carbon sink capacity of crop systems has attracted the attention of researchers. As crop soil ecosystems are net source or net sink of atmospheric $\mathrm{CO}_{2}$ ? Many studies have reported the carbon sink function of crops, such as wheatmaize-soybean rotation systems in black soils (Liang et al. 2012), paddy field system for long-term application of organic fertilizer (Hu et al. 2017), and no-till corn/soybean ecosystem (Bernacchi et al. 2005). Studies have also demonstrated that most of Chinese cropping systems are net source of GHG emissions (Wen et al. 2010). Hence, there are large variations of net GHG balance between different cropping systems or cultivation management. Thus, the carbon source/sink balance of tobacco soil ecosystem is rarely studied.

To cite this paper: Liang T, H Dai, Q Liu, Z Zhai, A Wang, Y Zhang (2021). Organic fertilizer regulates soil carbon, nitrogen balance and greenhouse gas emissions in tobacco production system. Intl J Agric Biol 25:1339-1345 
It is generally believed that application of organic fertilizer is an effective way to improve the soil and promote the growth of plants. The application of organic fertilizer can increase the number of soil microorganisms (Jannoura et al. 2014), improve the physical and chemical properties of soil, and regulate soil carbon pools (Lazcano et al. 2013; Liu et al. 2013; Wei et al. 2019). However, there are complex trade-offs between soil organic carbon (SOC) sequestration and GHG emissions, and the greenhouse effects of organic fertilizers remain controversial for field crops. Although organic fertilizers play an important role in increasing soil carbon sequestration and crop yield, their effects on GHG emissions cannot be ignored. Studies have shown that the application of organic fertilizer can promote the emission of $\mathrm{CO}_{2}$ and $\mathrm{N}_{2} \mathrm{O}$, and significantly enhance GHG warming potential (Zhu et al. 2013; Das and Adhya 2014). There are also reports on the use of organic fertilizers to increase soil carbon sinks (Sekhon et al. 2009; Yang et al. 2015; Hu et al. 2017). Therefore, the carbon sink effect of organic fertilizer varies among different crops and environment and few reports are available on the effect of organic fertilizers on soil carbon and nitrogen balance and GHG emissions in tobacco fields. To this end, the effects of different fertilization treatments on carbon and nitrogen gas emissions and comprehensive greenhouse effects of tobacco soil ecosystems are studied under the field condition, to provide a basis for tobacco field soil cultivation and GHG emission reduction.

\section{Materials and Methods}

\section{Experimental site and materials}

The experiment was conducted in Xiangcheng county, Xuchang city, Henan Province, China (N33 ${ }^{\circ} 51^{\prime}$, E $\left.113^{\circ} 25^{\prime}\right)$, from 2016 to 2017 . The soil type was cinnamon with basic physical and chemical properties with $\mathrm{pH} 7.89$, organic matter $17.20 \mathrm{mg} \cdot \mathrm{kg}^{-1}$, total nitrogen $1.10 \mathrm{mg} \cdot \mathrm{kg}^{-1}$, alkali nitrogen $76.54 \mathrm{mg} \cdot \mathrm{kg}^{-1}$, available phosphorus $23.16 \mathrm{mg} \cdot \mathrm{kg}^{-1}$, and available potassium $102.22 \mathrm{mg} \cdot \mathrm{kg}^{-1}$. The variety of fluecured tobacco tested was Zhongyan 100. The fertilizer applied was a special one for local tobacco, organic fertilizer (sesame cake fertilizer, $5.0 \% \mathrm{~N}$ content, $1.0 \% \mathrm{~K}_{2} \mathrm{O}$ content), compound fertilizer $\left(\mathrm{N}: \mathrm{P}_{2} \mathrm{O}_{5}: \mathrm{K}_{2} \mathrm{O}=10: 10: 10\right)$, and potassium sulfate $\left(50 \% \mathrm{~K}_{2} \mathrm{O}\right.$ content $)$.

\section{Experimental design}

The two-year randomized block experimental design was consistent. The experiment was comprised of three treatments: no fertilizer (CK), single application of chemical fertilizer (T1), combined application of chemical fertilizer and organic fertilizer (T2). The single application of chemical fertilizer was $375 \mathrm{~kg} \cdot \mathrm{hm}^{-2}$ as compound fertilizer and $225 \mathrm{~kg} \cdot \mathrm{hm}^{-2}$ as potassium sulfate. The combined application of chemical and organic fertilizer was $375 \mathrm{~kg} \cdot \mathrm{hm}^{-2}$ as organic fertilizer, 375 $\mathrm{kg} \cdot \mathrm{hm}^{-2}$ as compound fertilizer and $225 \mathrm{~kg} \cdot \mathrm{hm}^{-2}$ as potassium sulfate. The experiment used three replications, and the plot size of $100 \mathrm{~m}^{2}$.

All fertilizers were applied once before ridging. In 2016, fertilization and ridging were carried out on May 9, GHG collection began on May 10, and tobacco seedling transplanting was carried out on May 11. In 2017, the fertilization and ridging were performed on May 1, GHG collection on May 2, tobacco seedlings were transplanted on May 3. Other field management carried out was in accordance with local high quality tobacco production practices.

\section{Sample collection and analysis methods}

GHG were collected and measured using static chamberweather chromatography. The volume of the static box base (length $\times$ width $\times$ height) was $60 \mathrm{~cm} \times 50 \mathrm{~cm} \times 30 \mathrm{~cm}$, and the volume of the box (length $\times$ width $\times$ height) was $60 \mathrm{~cm}$ $\times 50 \mathrm{~cm} \times 15 \mathrm{~cm}$. Gas collection began after fertilization and ridging, which was carried out at 9:00-11:00 am at day $1,3,5,7,9,11,13,15,30,45,60,75,90$, and 115. The $\mathrm{CO}_{2}$ and $\mathrm{N}_{2} \mathrm{O}$ concentrations of the samples were determined using a GC7890 gas chromatograph (Agilent, U.S.A.).

Soil ammonia volatilization was measured by continuous chamber evacuation followed by titration. The closed chamber was made of transparent plexiglass material with an inner diameter of $20 \mathrm{~cm}$ and a device height of $30 \mathrm{~cm}$. There were two vent holes at the top of the chamber. One of the vents ( $30 \mathrm{~mm}$ in diameter) was connected to the vent tube containing the boric acid absorbing liquid filter bottle to reduce the influence of surface air exchange on the determination of ammonia volatilization. The other vent (11 $\mathrm{mm}$ in diameter) was connected to a gas cylinder containing boric acid absorbing liquid. The air in the sealed chamber was passed through a boric acid absorbing liquid by means of suction and decompression to absorb and fix the ammonia therein, and the collected solution was measured by a standard dilute sulfuric acid titration method. Samples were collected every day at 9:00-11:00 a.m. and 3:00-5:00 p.m. after fertilization. The cumulative amount of ammonia volatilization for a total of 15 days was used as the total emission.

At the maturity, samples of roots, stems and leaves of the plants were collected, dried and pulverized, and the carbon content of the plants was analyzed by Vario MARCO cube elemental analyzer (Elementar, Germany), and then the carbon fixation of the whole plant was calculated.

\section{Index calculation method}

The amount of change in $\mathrm{CO}_{2}$ was calculated using the formula:

\section{$\Delta \mathrm{SOC}=$ the carbon output - the carbon input}

Where, the carbon output is $\mathrm{CO}_{2}$ emission $\left(\mathrm{kg} \cdot \mathrm{hm}^{-2}\right)$; the carbon input is carbon from organic fertilizer $\left(\mathrm{kg} \cdot \mathrm{hm}^{-2}\right)$. 
Organic fertilizer carbon input (in terms of $\mathrm{CO}_{2}$ ) $=$ (amount of organic fertilizer applied $\times$ carbon content in organic fertilizer $\times 44) / 12$.

Nitrogen emissions $=$ ammonia volatilization $+\mathrm{N}_{2} \mathrm{O}$ emissions

The overall greenhouse effect of $\mathrm{CO}_{2}$ and $\mathrm{N}_{2} \mathrm{O}$ production in this study was characterized by $\mathrm{CO}_{2}$ equivalent, calculated as:

$\mathrm{CO}_{2}$-eq $\left(\mathrm{kg} \cdot \mathrm{hm}^{-2}\right)=\mathrm{N}_{2} \mathrm{O}$ emission $\left(\mathrm{kg} \cdot \mathrm{hm}^{-2}\right) \times 298+\Delta \mathrm{SOC}$ $\left(\mathrm{kg} \cdot \mathrm{hm}^{-2}\right)$.

The greenhouse gas emission intensity (GHGI) is the $\mathrm{CO}_{2}$ equivalent per unit of production, and the formula is:

GHGI $\left(\mathrm{kg} \cdot \mathrm{kg}^{-1}\right)=\mathrm{CO}_{2}$-eq $\left(\mathrm{kg} \cdot \mathrm{hm}^{-2}\right) /$ crop yield $\left(\mathrm{kg} \cdot \mathrm{hm}^{-2}\right)$.

\section{Statistical analysis}

Differences among different treatments were determined though one-way analysis of variance (ANOVA) and Least Significant Difference (LSD) test using S.P.S.S. 21.0 (S.P.S.S. software Inc., U.S.A.). Differences were considered significant at $P<0.05$.

\section{Results}

\section{Effect on soil $\mathrm{CO}_{2}$ emission flux}

Soil $\mathrm{CO}_{2}$ emission flux was largely affected by fertilization (Fig. 1). In 2016, within the first 15 days after fertilization, soil $\mathrm{CO}_{2}$ emission flux was at a relatively high level, and then decreased. The $\mathrm{CO}_{2}$ emission flux increased gradually 45 days after fertilization, and reached the highest at 90 days after fertilization followed by a rapid decline. In 2017, within 15 days after fertilization, the soil $\mathrm{CO}_{2}$ emission flux remained at a high level, and began to decline gradually after 75 days. The difference in soil $\mathrm{CO}_{2}$ emission flux during the year may be closely related to temperature and rainfall differences. Compared with the control, soil $\mathrm{CO}_{2}$ emission flux of chemical fertilizer treatment and combined chemical and organic fertilizer treatment increased significantly, and combined chemical and organic fertilizer treatment was slightly higher than chemical fertilizer treatment. Therefore, increasing application of organic fertilizer can promote soil $\mathrm{CO}_{2}$ emissions to a certain extent.

\section{Effect on soil carbon balance}

Compared with the control, the soil $\mathrm{CO}_{2}$ and $\mathrm{C}$ emissions of chemical fertilizer treatment and combined chemical and organic fertilizer treatment increased significantly, and the average increase reached $32.90 \%$ and $42.14 \%$ respectively (Table 1). Compared with chemical fertilizer treatment, both soil $\mathrm{CO}_{2}$ and $\mathrm{C}$ emissions increased in combined chemical and organic fertilizer treatment, with an average increase of $7.0 \%$, which may be closely related to organic fertilizers promoting soil microbial activity and improving soil physical and chemical properties. The carbon fixation of different treatments showed combined chemical and organic fertilizer treatment > chemical fertilizer treatment $>$ no fertilizer, which was consistent for two years. In 2016, under no fertilizer condition, the tobacco soil ecosystem is a carbon source to the atmosphere (net carbon output), while under normal fertilization conditions, it is a weak carbon sink (net carbon input). In 2017, due to the increase of carbon emissions and reduction of plants carbon sequestration, the tobacco soil system showed a carbon source. Compared with the application of chemical fertilizer alone, adding organic fertilizer significantly increased the carbon sequestration by plants and significantly increased the system carbon input.

\section{Effect on ammonia volatilization}

The ammonia volatilization of soil is mainly concentrated within the first 15 days after fertilization. In this study, the ammonia volatilization of all fertilization treatments fluctuated within the first 15 days of fertilization (Fig. 2). Compared with control, the ammonia volatilization level of chemical fertilizer treatment and combined chemical and organic fertilizer treatment increased significantly. Five days after fertilization, the ammonia volatilization level of combined chemical and organic fertilizer treatment was significantly higher than chemical fertilizer treatment.

\section{Effect on soil $\mathrm{N}_{2} \mathrm{O}$ emission flux}

The soil $\mathrm{N}_{2} \mathrm{O}$ emission mainly occurred within the first 15 days after fertilization (Fig. 3). Compared with control, the soil $\mathrm{N}_{2} \mathrm{O}$ emission fluxes from chemical fertilizer treatment and combined chemical and organic fertilizer treatment were significantly higher. There was an annual difference in the emission differences between chemical fertilizer treatment and combined chemical and organic fertilizer treatment. The $\mathrm{N}_{2} \mathrm{O}$ emission from chemical fertilizer treatment was higher than combined chemical and organic fertilizer treatment in 2016, while the difference between the two was smaller in 2017.

\section{Effect on soil nitrogen balance}

Soil $\mathrm{N}$ emission mainly comes from $\mathrm{N}_{2} \mathrm{O}$ and $\mathrm{NH}_{3}$.Compared with control, both the soil $\mathrm{N}$ emissions of chemical fertilizer treatment and combined chemical and organic fertilizer treatment increased significantly. The average increase of $\mathrm{N}$ emissions reached $74.72 \%$ and $93.86 \%$, respectively (Table 2). Compared with chemical fertilizer treatment, the $\mathrm{N}$ emission of combined chemical and organic fertilizer treatment was increased significantly, with an average increase of $11.79 \%$ in two years. The nitrogen accumulation of different treatments showed combined chemical and organic fertilizer > chemical fertilizer treatment $>$ control, which was consistent during two years. In 2017, due to the weak growth of tobacco plants and the low dry matter accumulation, the nitrogen accumulation of plants was significantly lower than 2016. 


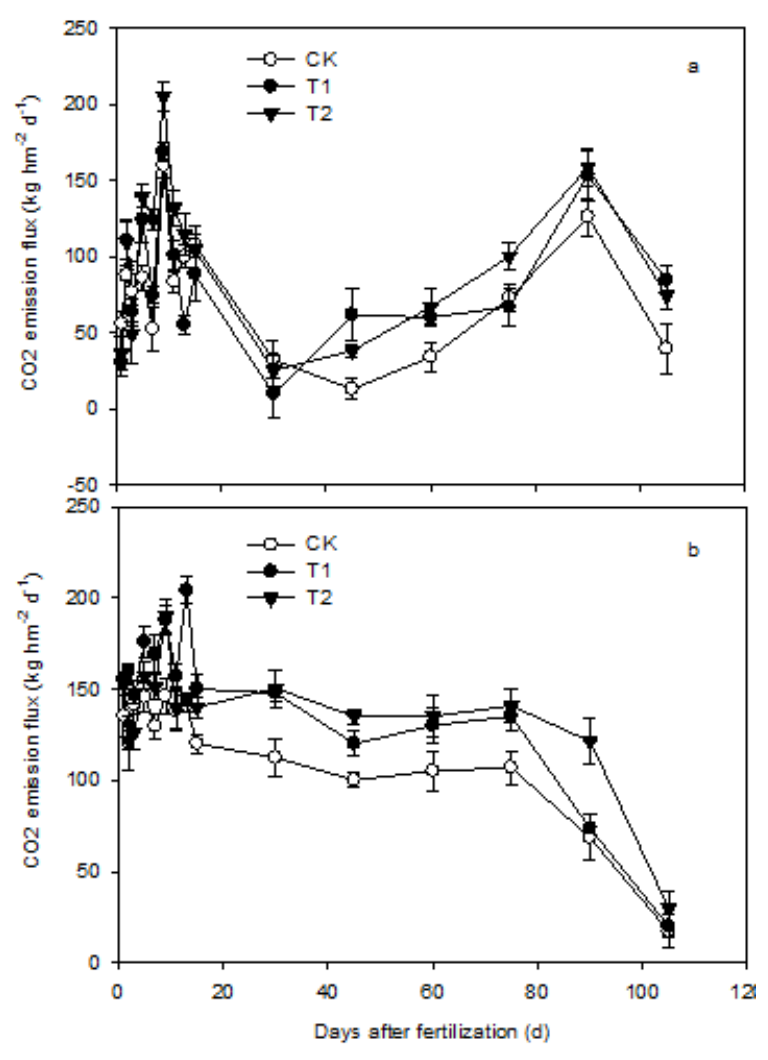

Fig. 1: Soil $\mathrm{CO}_{2}$ emission flux of different treatments during 2016 (a) and 2017 (b)

CK: no fertilizer, T1: chemical fertilizer, T2: chemical fertilizer + organic fertilizer

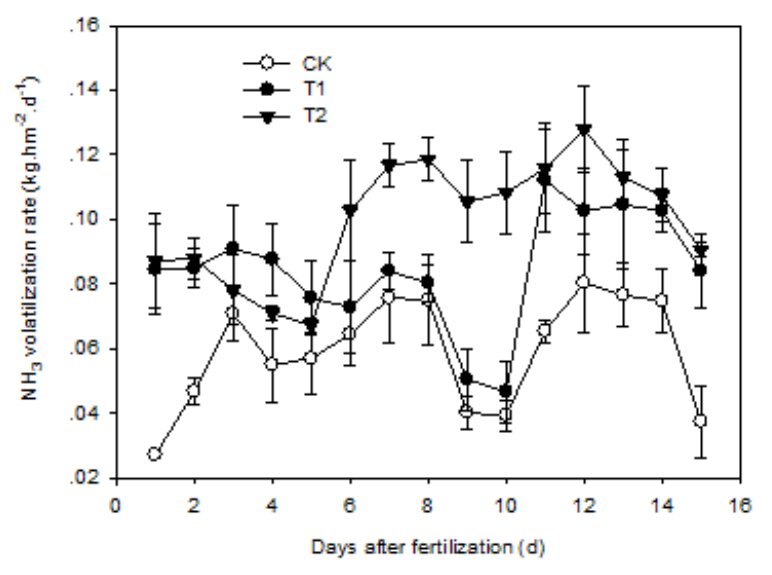

Fig. 2: Effect of different fertilization treatments on ammonia volatilization (two-year average)

CK: no fertilizer, T1: chemical fertilizer, T2: chemical fertilizer + organic fertilizer

\section{Effect on soil carbon emission intensity}

Compared with control, the $\mathrm{CO}_{2}$ change and the comprehensive greenhouse effect of chemical fertilizer treatment and combined chemical and organic fertilizer treatment increased significantly, but there was no significant difference between the two treatments (Table 3). Compared with control, chemical fertilizer treatment and

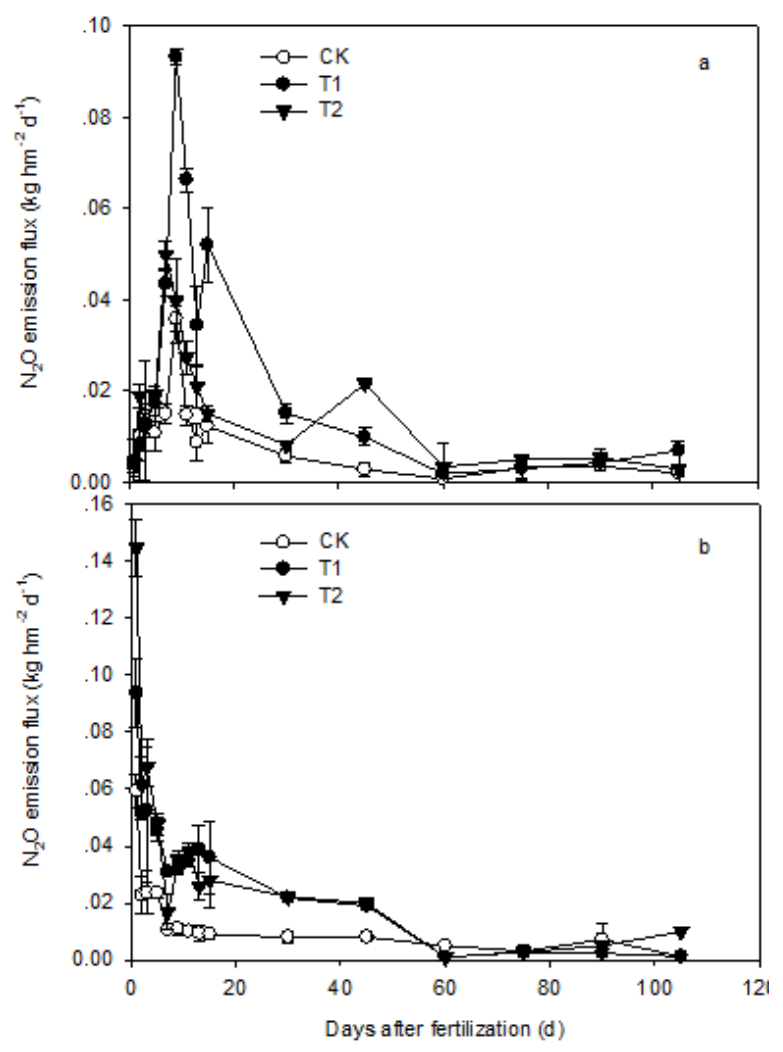

Fig. 3: Soil $\mathrm{N}_{2} \mathrm{O}$ emission flux of different treatments in 2016 (a) and 2017 (b)

CK: no fertilizer, T1: chemical fertilizer, T2: chemical fertilizer + organic fertilizer

combined chemical and organic fertilizer treatment significantly increased tobacco yield, and combined chemical and organic fertilizer treatment was significantly higher than chemical fertilizer treatment. The GHGI is the $\mathrm{CO}_{2}$ equivalent of the unit output, which is a comprehensive reflection of the economic benefits and environmental benefits brought by the fertilization measures. It can be seen that compared with control, the GHGI of chemical fertilizer treatment was significantly increased. So, the application of chemical fertilizer significantly increased the GHGI. Compared with chemical fertilizer treatment, the GHGI of combined chemical and organic fertilizer treatment decreased by $14.60 \%$ on average. It can be seen that the application of organic fertilizer was beneficial to increase the carbon sequestration and tobacco yield and slow down the greenhouse effect.

\section{Discussion}

Agricultural soil carbon source/sink balance and carbon sequestration potential have always been the focus of attention worldwide (Piao et al. 2009; Hadden and Grelle 2016; Miettinen et al. 2017). Studies have shown that there are significant differences in carbon sink capacities between different cropping systems. This study reported a significant annual variation in the carbon input in the tobacco 
Table 1: Effect of different fertilization treatments on carbon balance in tobacco production system

\begin{tabular}{llllll}
\hline Year & Treatment & $\mathrm{CO}_{2}$ emission $\left(\mathrm{kg} \mathrm{hm}^{-2}\right)$ & $\mathrm{C}$ emission $\left(\mathrm{kg} \mathrm{hm}^{-2}\right)$ & Plant carbon sequestration $\left(\mathrm{kg} \mathrm{hm}^{-2}\right)$ & Carbon input $\left(\mathrm{kg} \mathrm{hm}^{-2}\right)$ \\
\hline 2016 & CK & $7198.98 \pm 295.65 \mathrm{~b}$ & $1963.36 \pm 80.63 \mathrm{~b}$ & $1308.57 \pm 60.32 \mathrm{~b}$ & $-654.79 \pm 20.32 \mathrm{c}$ \\
& T1 & $10072.57 \pm 427.01 \mathrm{a}$ & $2747.06 \pm 116.45 \mathrm{a}$ & $2877.22 \pm 120.15 \mathrm{ab}$ & $130.16 \pm 3.69 \mathrm{~b}$ \\
& T2 & $10679.05 \pm 211.73 \mathrm{a}$ & $2912.47 \pm 57.74 \mathrm{a}$ & $2970.85 \pm 150.32 \mathrm{a}$ & $656.53 \pm 92.58 \mathrm{a}$ \\
2017 & CK & $10588.9 \pm 356.78 \mathrm{c}$ & $2887.88 \pm 97.30 \mathrm{c}$ & $1295.77 \pm 246.19 \mathrm{c}$ & $-1592.11 \pm 203.14 \mathrm{~b}$ \\
& T1 & $13328.45 \pm 443.15 \mathrm{~b}$ & $3635.03 \pm 120.85 \mathrm{~b}$ & $1969.97 \pm 203.58 \mathrm{~b}$ & $-1665.16 \pm 313.64 \mathrm{~b}$ \\
& T2 & $14394.45 \pm 467.52 \mathrm{a}$ & $3925.76 \pm 127.50 \mathrm{a}$ & $2647.46 \pm 176.67 \mathrm{a}$ & $-680.14 \pm 49.30 \mathrm{a}$ \\
\hline
\end{tabular}

CK: no fertilizer, T1: chemical fertilizer, T2: chemical fertilizer + organic fertilizer

Means showing the different letter are significantly different $(P<0.05)$ according to the LSD test

Table 2: Effect of different fertilization treatments on nitrogen balance in soil a tobacco production system

\begin{tabular}{lllll}
\hline Year & Treatment & $\mathrm{N}_{2} \mathrm{O}$ emission $\left(\mathrm{kg} \mathrm{hm}^{-2}\right)$ & $\mathrm{N}$ emission $\left(\mathrm{kg} \mathrm{hm}^{-2}\right)$ & Plant nitrogen accumulation $/\left(\mathrm{kg} \mathrm{hm}^{-2}\right)$ \\
\hline 2016 & $\mathrm{CK}$ & $0.51 \pm 0.05 \mathrm{~b}$ & $0.92 \pm 0.08 \mathrm{~b}$ & $73.97 \pm 6.88 \mathrm{~b}$ \\
& $\mathrm{~T} 1$ & $1.36 \pm 0.11 \mathrm{a}$ & $1.82 \pm 0.13 \mathrm{a}$ & $161.43 \pm 10.96 \mathrm{a}$ \\
& $\mathrm{T} 2$ & $1.16 \pm 0.10 \mathrm{a}$ & $1.92 \pm 0.16 \mathrm{a}$ & $169.30 \pm 15.23 \mathrm{a}$ \\
2017 & $\mathrm{CK}$ & $0.74 \pm 0.15 \mathrm{c}$ & $1.24 \pm 0.09 \mathrm{c}$ & $43.69 \pm 7.99 \mathrm{c}$ \\
& T1 & $1.34 \pm 0.12 \mathrm{~b}$ & $1.88 \pm 0.07 \mathrm{~b}$ & $91.00 \pm 9.81 \mathrm{~b}$ \\
& T2 & $1.62 \pm 0.15 \mathrm{a}$ & $2.22 \pm 0.09 \mathrm{a}$ & $115.87 \pm 12.52 \mathrm{a}$ \\
\hline
\end{tabular}

CK: no fertilizer, T1: chemical fertilizer, T2: chemical fertilizer + organic fertilizer

Means showing the different letter are significantly different $(P<0.05)$ in the LSD test

Table 3: Effects of different fertilization treatments on tobacco yield and soil carbon emission intensity

\begin{tabular}{|c|c|c|c|c|c|}
\hline Year & Treatment & $\mathrm{CO}_{2}$ change $\Delta \mathrm{SOC}\left(\mathrm{kg} \mathrm{hm}^{-2}\right)$ & Integrated greenhouse effect $\left(\mathrm{kg} \mathrm{hm}^{-2}\right)$ & Tobacco yield $\left(\mathrm{kg} \mathrm{hm}^{-2}\right)$ & $\begin{array}{l}\text { Greenhouse gas emission intensity } \\
\text { GHGI }\left(\mathrm{kg} \mathrm{kg}^{-1}\right)\end{array}$ \\
\hline \multirow[t]{2}{*}{2016} & $\mathrm{CK}$ & $7198.97 \pm 295.65 b$ & $7352.14 \pm 213.65 b$ & $1708.85 \pm 150.75 c$ & $4.30 \pm 0.20 b$ \\
\hline & $\mathrm{T} 1$ & $10072.57 \pm 427.01 \mathrm{a}$ & $10478.32 \pm 420.12 \mathrm{a}$ & $2190.09 \pm 217.54 b$ & $4.78 \pm 0.28 \mathrm{a}$ \\
\hline \multirow[t]{3}{*}{2017} & $\mathrm{CK}$ & $10588.90 \pm 356.78 b$ & $10808.82 \pm 401.48 b$ & $1436.25 \pm 75.60 \mathrm{c}$ & $7.53 \pm 0.36 b$ \\
\hline & $\mathrm{T} 1$ & $13328.45 \pm 443.15 \mathrm{a}$ & $13727.74 \pm 478.91 \mathrm{a}$ & $1668.75 \pm 103.20 b$ & $8.23 \pm 0.45 a$ \\
\hline & $\mathrm{T} 2$ & $13796.30 \pm 467.52 a$ & $14279.02 \pm 521.16 \mathrm{a}$ & $2025.00 \pm 150.00 a$ & $7.05 \pm 0.47 b$ \\
\hline
\end{tabular}

CK: no fertilizer, T1: chemical fertilizer, T2: chemical fertilizer + organic fertilizer

Means showing the different letter are significantly different $(P<0.05)$ in the LSD test

production system, acting as carbon source or weak carbon sink. The annual variation of carbon sink capacity in the tobacco soil system was closely related to the variation of plant biomass and carbon sequestration (Table 2). Fertilization can increase plant biomass and carbon sequestration capacity, and significantly increase the system's carbon sequestration capacity. The carbon sink effect of organic fertilizer depends on the biomass and carbon sequestration of the plant in addition to carbon emissions (Gai et al. 2019).

Soil carbon emissions from farmland are influenced by various factors such as fertilizer input, irrigation and conservation tillage (Gupta et al. 2016; Powlson et al. 2016; Zhong et al. 2016). Studies have shown that root respiration accounts for $20 \%$ of total soil respiration and microbial respiration accounts for $80 \%$ (Melillo et al. 2002). Organic fertilizers have an advantage in improving microbial activities (Francioli et al. 2016), which enhances soil respiration (Fernandez et al. 2016). Therefore, the higher $\mathrm{CO}_{2}$ emission and ammonia volatilization level of organic fertilizer treatment in this study may be related to the promotion of soil microbial activities. Organic fertilizer will mineralize and release $\mathrm{CO}_{2}$ if it is not applied to farmland. Hence, $\mathrm{CO} 2$ produced by organic fertilizer induced soil respiration does not increase atmospheric $\mathrm{CO}_{2}$ concentration (Li et al. 2015). The release of $\mathrm{CO}_{2}$ from the mineralization of the original organic matter in the soil is an important hazard affecting $\mathrm{CO}_{2}$ in the atmosphere. Application of organic fertilizer is an effective measure to increase the soil carbon pool and reduce the greenhouse effect (Andreas et al. 2015). Under the conditions of this experiment, compared with single application of chemical fertilizer, the application of organic fertilizer increased the $\mathrm{CO}_{2}$ emission flux and $\mathrm{C}$ emission of the soil to a certain extent, and significantly increased the carbon sequestration of the plant, thus improving the carbon sink capacity of the tobacco production system.

In terms of nitrogen balance, the source of soil $\mathrm{N}_{2} \mathrm{O}$ was mainly the transformation from fertilizer nitrogen, and its emission was mainly occurred within the 15 days after fertilization. Compared with single application of chemical fertilizer, the application of organic fertilizer can increase the $\mathrm{N}_{2} \mathrm{O}$ emission flux of soil to some extent. Meanwhile, the application of organic fertilizer can increase ammonia volatilization level from the soil, which may be related to the promotion of soil microbial activities. Studies have showed that $\mathrm{N}_{2} \mathrm{O}$ emissions from conventionally managed soils seemed to be influenced mainly by total $\mathrm{N}$ inputs, whereas for organically managed soils other variables such as soil characteristics seemed to be more important (Wei et al. 2014). The application of organic fertilizer increased the $\mathrm{N}$ emission while significantly increased the nitrogen fixation of the plant, which significantly improved the nitrogen fixation capacity of the soil tobacco ecosystem. 
GHGI is a comprehensive indicator of the economic and environmental benefits of fertilization measures. Compared with single application of chemical fertilizers, adding organic fertilizer significantly increased the yield of tobacco leaves, thus ensuring a lower GHGI value. Under the condition of this experiment, the GHGI of organic fertilizer application decreased by an average of $14.60 \%$, and the emission reduction effect was significant. Therefore, proper application of organic fertilizer is an important way to ensure crop yield, improve soil quality, and achieve carbon sequestration.

\section{Conclusion}

Adding organic fertilizer can increase the $\mathrm{CO}_{2}$ and $\mathrm{N}_{2} \mathrm{O}$ emission flux of the soil to a certain extent, and increase the $\mathrm{C}$ and $\mathrm{N}$ emissions. However, organic fertilizer application can increase plant carbon sequestration and tobacco leaf yield, significantly reducing GHGI, and improving soil quality and carbon sequestration. The tobacco soil ecosystem is carbon source or weak carbon sink, which depends mainly on the carbon sequestration of the plant. The carbon sink effect of organic fertilizer is also closely related to the growth of the tobacco plant.

\section{Acknowledgments}

This work was supported by science and technology key project of China National Tobacco Corporation (11201902004, 110201402015).

\section{Author Contributions}

TL carried out experiments and wrote the paper. HD analyzed the data and wrote the paper. Q.L. contributed to the Figures. ZZ carried out experiments. AW contributed in Carbon analysis. YZ contributed to experiment design and research management.

\section{Conflict of Interest}

There is no conflict of interest among the authors and the institutions where the research has been conducted.

\section{Data Availability}

All data reported in this article are available with the corresponding author and will be produced on demand.

\section{Ethics Approval}

Not applicable

\section{References}

Andreas G, S Colin, M Adrian, M Paul, N Urs (2015). Soil organic carbon dynamics and non- $\mathrm{CO}_{2}$ gas fluxes from agricultural soils under organic and non-organic management - results of two meta-studies. In: EGU general assembly, p: 8334
Bernacchi CJ, SE Hollinger, T Meyers (2005). The conversion of the corn/soybean ecosystem to no-till agriculture may result in a carbon sink. Glob Change Biol 11:1867-1872

Das S, TK Adhya (2014). Effect of combine application of organic manure and inorganic fertilizer on methane and nitrous oxide emissions from a tropical flooded soil planted to rice. Geoderma 213:185-192

Duiker SW, R Lal (1999). Crop residue and tillage effects on carbon sequestration in a luvisol in central Ohio. Soil Till Res 52:73-81

Fernandez AL, SCC heaffer, DL Wyse, C Staley, TG Gould, MJ Sadowsky (2016). Associations between soil bacterial community structure and nutrient cycling functions in long-term organic farm soils following cover crop and organic fertilizer amendment. Soil Total Environ 566:949-959

Francioli D, E Schulz, G Lentendu, T Wubet, F Buscot, T Reitz (2016). Mineral vs. organic amendments: microbial community structure, activity and abundance of agriculturally relevant microbes are driven by long-term fertilization strategies. Front Microbiol 7; Article 1446

Gai XP, HB Liu, B Yang, HY Wang, LM Zhai, QL Lei, SX Wu, TZ Ren (2019). Responses of crop yields, soil carbon and nitrogen stocks to additional application of organic materials in different fertilization years. Sci Agric Sin 52:676-689

Gao B, T Huang, XT Ju, BJ Gu, W Huang, LL Xu, RM Rees, DS Powlson, P Smith, SH Cui (2018). Chinese cropping systems are a net source of greenhouse gases despite soil carbon sequestration. Glob Change Biol 24:5590-5606

GuptaDK, A Bhatia, A Kumar (2016). Mitigation of greenhouse gas emission from rice-wheat system of the Indo-Gangetic plains: Through tillage, irrigation and fertilizer management. Agric Ecosyst Environ 230:1-9

Hadden D, A Grelle (2016) Changing temperature response of respiration turns boreal forest from carbon sink into carbon source. Agric For Meteorol 223:30-38

Hu ZH, DM Li, XL Xu, XC Yu, KL Liu, HC Ye, LJ Zhou, HW Hu, QH Huang (2017). Evaluation of net carbon sink effects and costs/benefits of double-cropped rice fields under different organic fertilizer applications. Chin J Eco-Agric 25:157-165

Jannoura R, RG Joergen, C Bruns (2014). Organic fertilizer effects on growth, crop yield, and soil microbial biomass indices in sole and intercropped peas and oats under organic farming conditions. Eur $J$ Agron 52:259-270

Lange M, N Eisenhauer, CA Sierra, H Bessler, C Engels, RI Griffiths, PG Mellado-Vázquez, AA Malik, J Roy, S Scheu, S Steinbeiss, BC Thomson, SE Trumbore, G Gleixner (2015). Plant diversity increases soil microbial activity and soil carbon storage. Nat Commun 6; Article 6707

Lazcano C, M Gómez-Brandón, P Revilla, J Domínguez (2013). Short-term effects of organic and inorganic fertilizers on soil microbial community structure and function. Biol Fert Soils 49:723-733

Li YQ, JW Tang, SG Che, YC W, WW Sun, BQ Zhao (2015). Effect of organic and inorganic fertilizer on the emission of $\mathrm{CO}_{2}$ and $\mathrm{N}_{2} \mathrm{O}$ from the summer maize field in the north China plain. Sci Agric Sin 48:4381-4389

Liang Y, XZ Han, YF Qiao, LJ Li, MY You (2012). Soil respiration and carbon budget in black soils of wheat maize-soybean rotation system. Chin J Eco-Agric 20:395-401

Liu EK, C Yan, X Mei, ZY hang, T Fan (2013). Long-term effect of manure and fertilizer on soil organic carbon pools in dryland farming in northwest China. PLoS One 8; Article e56536

Melillo JM, PA Steudler, JD Aber, K Newkirk, H Lux, FP Bowles, C Catricala, A Magill, T Ahrens, S Morrisseau (2002). Soil warming and carbon-cycle feedbacks to the climate system. Science 298:2173-2176

Miettinen J, A Hooijer, R Vernimmen, SC Liew, SE Page (2017). From carbon sink to carbon source: extensive peat oxidation in insular Southeast Asia since 1990. Environ Res Lett 12:024014

Piao SL, JY Fang, P Ciais, P Peylin, Y Huang, S Sitch, T Wang (2009). The carbon balance of terrestrial ecosystems in China. Nature 458:10091013

Poeplau C, A Don (2015) Carbon sequestration in agricultural soils via cultivation of cover crops - A meta-analysis. Agric Ecosyst Environ 200:33-41 


\section{Organic Fertilizer Regulates Greenhouse Gas Emissions / Intl J Agric Biol, Vol 25, No 6, 2021}

Powlson DS, CM Stirling, C Thierfelder, RP White, ML Jat (2016). Does conservation agriculture deliver climate change mitigation through soil carbon sequestration in tropical agro-ecosystems? Agric Ecosyst Environ 220:164-174

Sekhon KS, JP Singh, DS Mehla (2009). Soil organic carbon pools after seven years of manures and mineral fertilizers application in a ricewheat rotation. Arch Agron Soil Sci 55197-206

Smith P, D Martino, Z Cai, D Gwary, H Janzen, P Kumar, P McCarl, S Ogle, F O'Mara, C Rice, B Scholes, O Sirotenko, M Howden, T McAllister, GX Pan, V Romanenkov, U Schneider, S Towprayoon (2007). Policy and technological constraints to implementation of greenhouse gas mitigation options in agriculture. Agric Ecosyst Environ 118:6-28

Tian HQ, CQ Lu, P Ciais, AM Michalak, JG Canadell, E Saikawa, DN Huntzinger, KR Gurney, S Sitch, BW Zhang, J Yang, P Bousquet, L Bruhwiler, GS Chen, E Dlugokencky, P Friedlingstein, J Melillo, SF Pan, B Poulter, R Prinn, M Saunois, CR Schwalm, SC Wofsy (2016). The terrestrial biosphere as a net source of greenhouse gases to the atmosphere. Nature 531:225-228

USEPA (2006). US Environmental Protection Agency. Global Emissions of Non- $\mathrm{CO}_{2}$ Greenhouse Gases: 1990-2020. Washington DC, USA
Wei M, AJ Zhang, Y Chao, H Wang, H Pan, YH Lou, YP Zhuge (2019). Long-term effect of fertilizer and manure application on the balance of soil organic carbon and yield sustainability in fluvo-aquic soil. Arch Agron Soil Sci 65:1-12

Wei W, K Isobe, Y Shiratori, T Nishizawa, N Ohte, S Otsuka, K Senoo (2014). $\mathrm{N}_{2} \mathrm{O}$ emission from crop land field soil through fungal denitrification after surface applications of organic fertilizer. Soil Biol Biochem 69:157-167

Wen H, Zhong, T Gu, W Wang, B Zhang, XG Lin, QR Huang, WS Shen (2010). The effects of mineral fertilizer and organic manure on soil microbial community and diversity. Plant Soil 326:511-522

Yang B, ZQ Xiong, JY Wang, X Xu, Q Huang, Q Shen (2015). Mitigating net global warming potential and greenhouse gas intensities by substituting chemical nitrogen fertilizers with organic fertilization strategies in rice-wheat annual rotation systems in China: A 3-year field experiment. Ecol Eng 81:289-297

Zhong YM, XP Wang, JP Yang, X Zhao, XY Ye (2016). Exploring a suitable nitrogen fertilizer rate to reduce greenhouse gas emissions and ensure rice yields in paddy fields. Soil Total Environ 565:420-426

Zhu TB, JB Zhang, WY Yang, ZC Cai (2013). Effects of organic material amendment and water content on $\mathrm{NO}, \mathrm{N}_{2} \mathrm{O}$ and $\mathrm{N}_{2}$ emissions in a nitrate-rich vegetable soil. Biol Fert Soils 49:153-163 